\title{
Political stability and innovation in Africa
}

\author{
James Okrah \\ Ural Federal University/ GSEM, \\ Ekaterinburg, Russia \\ jokrab6@gmail.com
}

Marzena Hajduk-Stelmachowicz

Department of Economics,

Rzeszow University of Technology

Poland

marzenah@prz.edu.pl

ORCID 0000-0003-4945-7207

Abstract. This paper examines the role of institutional factors, primarily, political stability, in shaping the dynamics of innovation activity in today's modern society. Using panel data consisting of 26 African countries from the period between 1996 and 2016 as well as employing the negative binomial estimate, we model the impact of those factors on the number of applications for patents per resident. GDP per capita, education and also other institutional factors including the rule of law and financial freedom. The results reveal a strong positive effect of the rule of law on patenting activity.

Received:

September, 2019

1st Revision:

January, 2020

Accepted:

February, 2020

DOI:

$10.14254 / 2071$ $8330.2020 / 13-1 / 15$

Keywords: innovations, patent activities, institutions and organisations, political stability, rule of law, entrepreneurship.

JEL Classification: O3, O55, F55, K10, M14

\section{INTRODUCTION}

The business ecosystem has experienced a swift evolution within the past two decades. The process of doing business has been exposed to new technological and structural changes in the business world, which has resulted in the failure of a number of businesses to maintain their position on the market. A hundred years ago one (1) in three (3) American workers were employed on a farm. Today, less than 2\% of them are able to produce much more food (The Economist, 2018). During the industrial revolution, factories and machines replaced many jobs and increased productivity.

Many factors (especially innovation) are crucial for economic growth competitiveness in the current era. Innovation is the pivot of every successful corporation. Customer options are wider than before and 
newcomers are disrupting established industries. For companies trying to adopt new ways of improving their innovation practices, there is one factor that is key to determining the success or failure of the innovation system. This is referred to as "The rule of the game". Organisations are shaped by institutions and in turn, influence the way in which the institutions change (DiMaggio \& Powell, 1983:147-60). Some social scientists view organisations as the material expressions of institutions. Some perceive social groups such as government bodies, tribes and families as institutions. Some identify 'primary' or 'meta' institutions to be the family, government, economy, education and religious groups. (North, 1990: 3, 5; Harper et al., 2012: 15).). As far as the institutional perspective is concerned 'organizations are suspended in a web of values, norms, beliefs, and taken - for granted assumptions'. (Barley\&Tolbert 1997:93). 'Organizations that share the same environment tend to take on similar forms as efficiency-seeking organizations seek the optimal 'fit' with their environment' (Boxenbaum \& Jonsson 2008:78)

No matter the effort put in by a corporation to innovate, its success depends on the functioning of the institutions - written constitution, laws, policies, rights, regulations enforced by official authorities, trust, and culture are the baseline for the success and failure of many companies. A very clear example of this is the postal system in Western Europe and in West Africa, particularly Ghana. The postal system in Ghana was adopted from the one present in the United Kingdom (UK), and although it is considered to function very effectively in the UK, the same cannot be said of the postal system in Ghana. This is because the UK government has implemented good policies that ensure the continuous and smooth running of the postal system but unfortunately the postal system of Ghana has lost its effectiveness because of the internet and a lack of good solutions proposed by the government to support this system. According to the Universal Postal Union (UPU) ranking in 2017, Ghana was ranked at 92nd and the UK 6th. This ranking is based on four criteria, i.e. reliability, reach, relevance and resilience (Integrated index for postal development (2IPD), 2016).

A plethora of research has focused on the institutional effect involving such factors such as trust (Guiso et al, 2003, Danaj et al., 2018), religion (Weber, 1905) and property rights (Denison \& KlinglerVidra, 2012) on economic growth. Notwithstanding, there remains a gap - the distortion of this effect under the influence of institutional factors has not been analyzed.

This study is aimed at investigating the impact of disruption of political stability on the innovations introduced by companies in Africa and their patenting activity. With this objective in mind, we used crosssectional data from the period between 1996 and 2016, in reference to 26 countries. We will apply the negative binomial estimates, since the analysed dependent variable is the number of patent applications submitted by residents.

We confirmed that, the rule of law has a positive influence on patenting activities, thereby increasing the confidence of the business community, and we also confirmed that political instability is negatively significant to innovation in firms.

Our work is structured as follows: the next section is devoted to the role of institutional factors for innovation, we then describe the methodology of our research, characterize the data used and then present the results and discussion.

\section{LITERATURE REVIEW}

From the 1980s onwards, innovation system studies have pointed out the influence of the social system on innovative performance. Institutions are the bedrock of every economy - better institutions foster growth in the economy and serves as motivation for entrepreneurial activities.

The integration of institutions in economic theory is used as an explanation of the cross country differences in economic performance (Acemoglu \& Johnson, 2004, Classens \& Leaven, 2003, Knack et al, 
1995). Institutions play a significant role in the process of decision-making, by increasing the predictability of the decision-making situations and by setting rules that govern the players, allowable actions and strategies, authorized results and links between decisions (Heywood, 2000, Hajduk-Stelmachowicz, 2018, Witkowska et al., 2019). Good institutions foster growth and give investors incentives to invest in an economy.

There are two types of institutions, i.e. formal ones and informal ones, and both of them are relevant to this research. Formal institutions include the written constitution, laws, policies, rights and regulations enforced by official authorities (Leftwich\& Sen, 2010; Berman, 2013). Helmke and Levitsky (2004) define formal institutions as openly codified, in the sense that they are established and communicated through channels that are widely accepted as official. These macroeconomic institutions influence the decisions of investors and managers on their approach to business and innovation. Informal institutions are (the usually unwritten) social norms, customs or traditions that shape the way of thinking and behavior (Leftwich \& Sen, 2010; Berman, 2013). Helmke \& Levitsky (2004) define informal institutions as socially shared rules, usually unwritten, that are created, communicated and enforced outside of official channels. Informal institutions change very slowly compared with formal institutions. In practice, formal and informal rules and norms can be complementary, competing or overlapping (Jütting et al., 2007: 36; Leftwich \& Sen, 2010: 17). Whether they are relatively stronger/weaker or inclusive/discriminatory is likely to depend on the context (Unsworth, 2010). In some cases, informal institutions undermine the formal ones; in others they substitute for them (Leftwich \& Sen, 2010; Jütting et al., 2007). Informal social norms often shape the design and implementation of formal state institutions (Migdal, 2001; Jütting et al., 2007).

Alesina, Ozler, Roubini and Swagel discovered that countries with a high incidence of government collapse are characterised by low economic growth, though they also revealed that low economic growth does not affect political instability (Alesina, et al., 1996). Japan, after the second world war, practiced import substitutionto build its economy and when things became better it started to promote export and import with no tariff barriers. Instead non-tariff barriers were used. China and India followed in their footsteps and the result is quite evident, as China is now the second strongest economy in the world after the USA. However, when this same system was adopted by Ivory Coast, Costa Rica, Honduras and Togo, it did not contribute to a significant improvement in the economic situations of these countries in any way. The adoption of a good policy does not work for every country due to: (a) the political climate and (b) the lack of good institutions. The cases of Ivory Coast and Togo clearly bring this to light. Political instability affects growth because it increases political uncertainty, which has negative effects on productive economic decisions related to investments and savings. A high probability of a change in government implies uncertain future policies, and risk-averse economic agents may wait to take productive economic initiatives or might even "exit" the economy by investing abroad. Similarly, foreign investors are likely to prefer a stable political environment (Alesina et al., 1996). Waguespack et al. (2005) states that political stability is an indicator of economic prospects; hence if this factor is absent, investors find it extremely unlikely to venture into such economies. The non-performance of developed countries when they adopt a working policy is a problem that should be addressed.

The insufficient protection of property rights is one of the reasons that prevent a lot of people from registering their patent in their own countries. Property rights literature is primarily concerned with two principal issues: (a) the reduction in investors' risk and an increase in incentives to invest, and (b) improvements in household welfare; the researchers explored the channels through which property rights affect growth and household welfare in developing countries (Denison \& Klingler-Vidra, 2012). Alchian \& Armen, (2008) state that property rights can be viewed as an attribute of economic well-being. When there is a good property rights policy that ensures the safety of the intellectual properties of its people, it 
encourages people to contribute to their own economies. But do property rights have any effect on a corporation's willingness to innovate?

Corruption has hindered the progress of a lot of developing countries (Navickas et al., 2016; Draskovic et al., 2019). When these institutional factors are not considered, the process of the innovation system becomes stagnant, and people, investors and industries lose confidence in their societies (SzalachaJarmużek \& Pietrowicz, 2018; Jovovic et al., 2017). When this happens the people prefer to invest their capital in corruption-free and stable countries with good institutions (Chudy-Laskowska et al., 2017).

There are many talented scientists who have migrated to others countries because of the institutional conditions in their countries. The issue of corruption has not been addressed so far with regards to its effects on innovation.

\section{Institutions and Innovation Activity}

Table 1

Countries with the best and worst Institutions

\begin{tabular}{|c|c|c|c|}
\hline \multicolumn{2}{|c|}{ Top 20 Countries with the best institutions (2018) } & \multicolumn{2}{|c|}{$\begin{array}{l}\text { The bottom } 20 \text { countries with the worst institutions } \\
\text { (2018) }\end{array}$} \\
\hline Country & Score $0-100$ (best) & Country & Score $0-100$ (best) \\
\hline New Zealand & 81.6 & Iran, Islamic Rep. & 44.3 \\
\hline Finland & 81 & Nicaragua & 43.9 \\
\hline Singapore & 80.7 & Guatemala & 43.5 \\
\hline Netherlands & 77.9 & Zimbabwe & 43 \\
\hline Switzerland & 77.1 & Cameroon & 43 \\
\hline Hong Kong SAR & 76.9 & Cambodia & 41.9 \\
\hline United Kingdom & 76.8 & Nigeria & 41.7 \\
\hline Norway & 76.7 & Guinea & 41.6 \\
\hline Sweden & 76 & Bolivia & 41.2 \\
\hline Denmark & 75.9 & Mozambique & 41.2 \\
\hline Canada & 75.5 & El Salvador & 40.7 \\
\hline Luxembourg & 75.2 & Mali & 40.3 \\
\hline United States & 74.6 & Mauritania & 38.4 \\
\hline Iceland & 74.3 & Angola & 37.2 \\
\hline Australia & 73.6 & Burundi & 36.3 \\
\hline Germany & 73.5 & Congo, Democratic Rep. & 36 \\
\hline Ireland & 73.1 & Chad & 34.6 \\
\hline Austria & 72.7 & Haiti & 32.9 \\
\hline United Arab Emirates & 71.8 & Yemen & 29.5 \\
\hline Japan & 71.1 & Venezuela & 27.3 \\
\hline
\end{tabular}

Source: Own elaboration. The data come from The Global Competitive Report 2018. (The World Economic Forum, 2018). 
Note: The table above shows the top 20 countries with good institutions and the bottom 20 countries with the worst institutions in the year 2018. For individual indicators, prior to aggregation raw values are transformed into a progress score ranging from 0 to 100, with 100 being the ideal state (best). Institutions pillar index components are: Organized crime, Homicide rate, Terrorism incidence, Reliability of police services, Social capital, Budget transparency, Judicial independence, Efficiency of legal framework in challenging regulations, Freedom of the press, Burden of government regulation, Efficiency of legal framework in settling disputes, E-Participation Index, Future orientation of government, Incidence of corruption, Property rights, Intellectual property protection, Quality of land administration, Strength of auditing and reporting standard, Conflict of interest regulation, Shareholder governance. For individual indicators, prior to aggregation raw values are transformed into a progress score ranging from 0 to 100 , with 100 being the ideal state (best). Institutions pillar index components are: Organized crime, Homicide rate, Terrorism incidence, Reliability of police services, Social capital, Budget transparency, Judicial independence, Efficiency of legal framework in challenging regulations, Freedom of the press, Burden of government regulation, Efficiency of legal framework in settling disputes, E-Participation Index, Future orientation of government, Incidence of corruption, Property rights, Intellectual property protection, Quality of land administration, Strength of auditing and reporting standard, Conflict of interest regulation, Shareholder governance.

According to the World Competitive Report 2018 weak institutions continue to hamper/hinder competitiveness, development and well-being in many countries. Governments must pay attention to both traditional and emerging knowledge about strengthening the institutional environment as a factor of productivity. The Institutions pillar is the second-lowest Summary of Key Findings scoring pillar of the 12 The Global Competitiveness Index 4.0 pillars (after the Innovation capability pillar), with a median score of 53 - just over halfway to the frontier. For 117 of the 140 economies studied, their Institutions pillar performance is a drag on their overall competitiveness score.

Table 1. shows the top 20 and the bottom 20 countries with strong and poorly developed institutions respectively, in the bottom 20 institutionally weak states, there are as many as 13 African countries. The institution variable in the world competitive report takes into account, security, social capital, checks and balances, public sector performance, transparency, property rights and corporate governance. In the ranking of institutions, there are only 2 African countries in the top 50 countries. These are Rwanda (29th) and Mauritius $\left(38^{\text {th }}\right)$. This demonstrates why the GEM report shows that the perception of opportunities is high in Africa but there are less successes in entrepreneurship, except in a few cases.

Figure 1 shows the map of the innovation ecosystem and institutions, the data on the innovation ecosystem takes into account business dynamism, entrepreneurial culture, innovation capacity, multishareholder collaboration as well as interaction and diversity. The size of the circles shows the Innovation Ecosystem of the country - the bigger the circle is the better the innovation ecosystem. All the countries with big circles are also those countries with better institutions. Institutions are indicated by the colour., Dark blue indicates better institutions, and as the colour fades to lighter blue, this indicates countries with weaker institutions. The map shows a clear picture of weaker institutions in Africa, specifically SubSaharan Africa. We conducted a further test to verify whether institutions have a direct effect on the innovation ecosystem or not. 


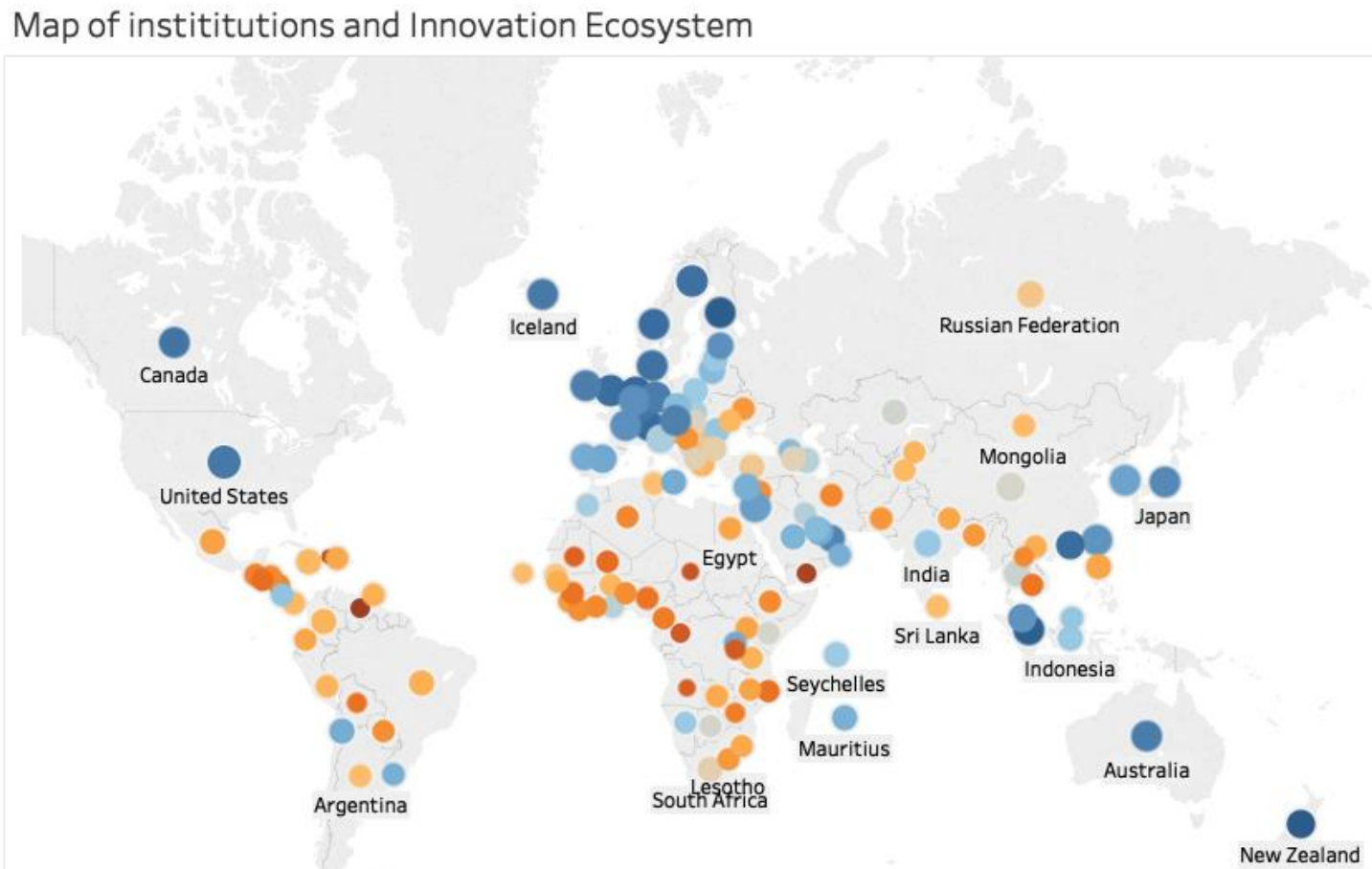

Figure 1. Map of the innovation ecosystem and institutions

Source: Own elaboration. The data come from The Global Competitive Report 2018.

(The World Economic Forum, 2018).

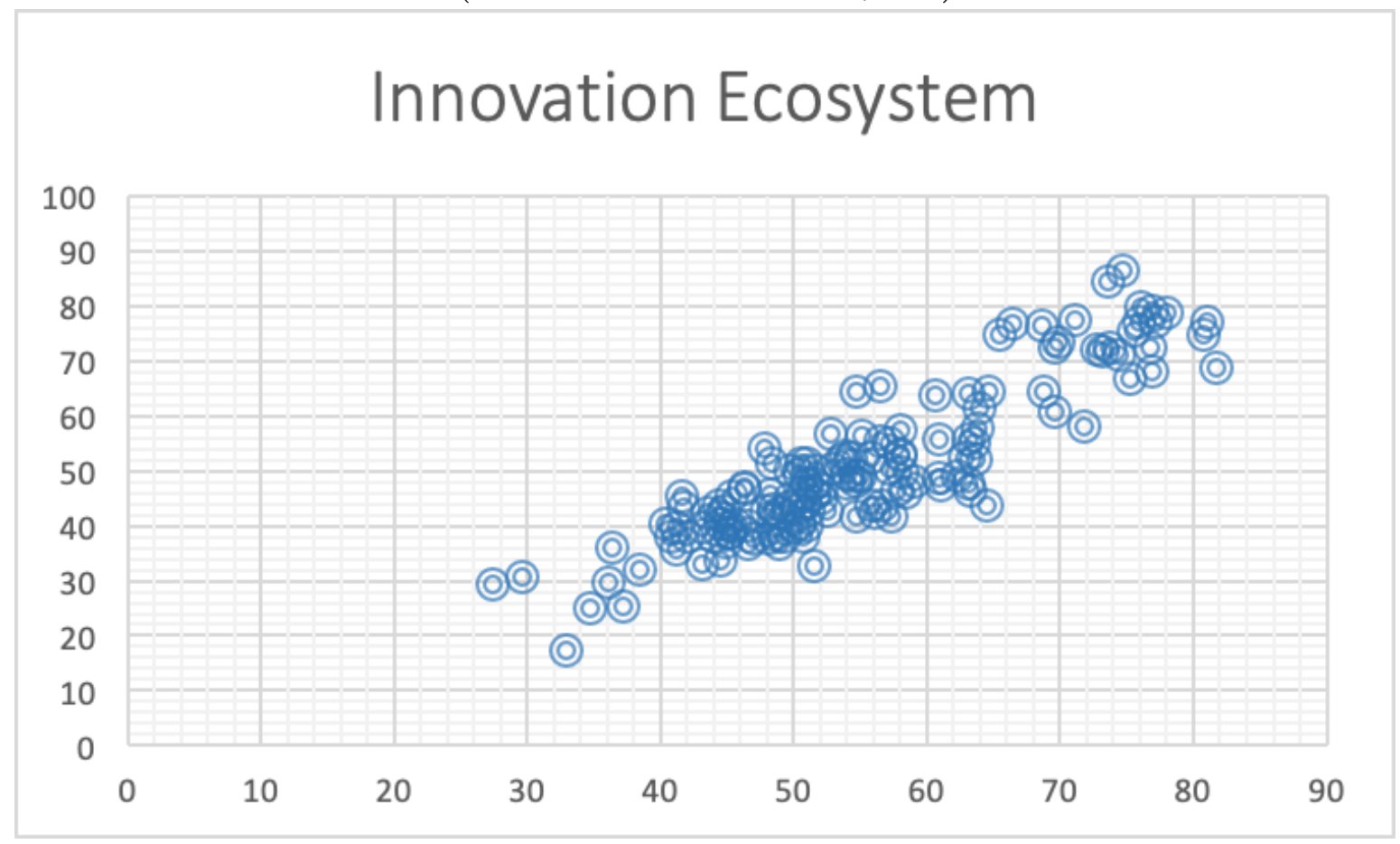

Figure 2. Innovation Ecosystem

Source: Own elaboration 
Figure 2 shows that there is a linear relationship between institutions and the innovation ecosystem. With this as a basis, we wanted to discover the extent to which institutions influence businesses and patent activities in African economies. We took into consideration political stability to see if it is a determinant in the promotion of patent activity and business innovation in Africa.)

\section{RESEARCH METHOD}

The main purpose of our study is to study the impact of political stability on innovation in companies.

As dependent variables, we investigated the number of patent applications per resident - one of the main characteristics of innovation activity. The number of patents and R\&D projects are considered to be the main characteristics of innovation activity (Ortiz-Villajos \& Sotoca, 2018; Jaffe \& Palmer, 1997). In this study we use patent applications as the dependent variable. We also identify the distortion effect of political stability on patent applications. To do this, we investigate the influence of such institutional factors as rule of law, financial freedom, and the percentages of Christians and Muslims in the populations.

To formulate and justify the scientific deficit, which our model is aimed at eliminating, we proposed the following hypothesis.

HO: The growth of political stability affects the number of patents submitted. Waguespack, et.al (2005) claims that political stability is a relevant factor for patent applications. In circumstances where political stability is the greatest, and hence political uncertainty is the lowest, one should expect a more aggressive pursuit of intellectual property rights. Hoti \& McAleer (2006) show that political risk ratings have a considerable impact on innovative activities.

H1: A growth in confidence increases the number of patents submitted and positively influences the effect of political stability on Research and Development. Hoti \& McAleer (2006) and Pittawayetal.(2004) indicated that when there are fewer political risks and the political stability is higher the people's shared desire for creativity is increased because they know they can protect their patents from the risk of theft.

\section{Basic Model}

Since our dependent variable is a count variable, in order to get a true picture of our data, we take into account the work of Zeileis et al. (2008). In order to capture the relationship between the number of applications per resident and all regressors, we have applied the basic Poisson regression model. All coefficients are highly significant. However, as the Wald test results may be too optimistic due to a misspecification of the likelihood, we re-computed the Wald tests using the sandwich standard errors method. To confirm the over-dispersion of the dependent, we performed the dispersion test. The result of the test indicates over-dispersion. The results are presented below.

Over-dispersion test

$$
\mathrm{z}=5.3772, \mathrm{p} \text {-value }=3.782 \mathrm{e}-08
$$

alternative hypothesis: true dispersion is greater than 1

sample estimates: dispersion 142.8274

Since the results of the over-dispersion test indicate over-dispersion in the dependent variable we used the negative binomial for further testing and reporting.

To analyze the effect of the variables in the study, we integrated GDP per capita into our models as a control variable. When we studied GDP, we did not pretend it to scientific novelty. We considered this variable only as a basic variable with a proven effect on patent application (Yuel, 2009), (Kolmakov et al. 2015), and (Khalili et al. 2016). Based on this database, we analyzed the investigated variables. We also considered education and unemployment as control variables. 


\subsection{Data}

To investigate the problem identified, our data includes a panel of annual observations from 26 African countries from the years 1996-2016 with 567 observations. The reason for the selection of these countries is due to the availability of data, that is, the countries with no patents were excluded. Most of our data comes from the World Bank and WIPO.

The table below shows the basic statistics of the dependent and independent variables.

Table 2

Statistics Summary

\begin{tabular}{|l|c|c|c|c|}
\hline Variables & Observation & Mean & Standard deviation & Max \\
\hline Patent.P.R & 567 & 65.66 & 182.13 & 1003 \\
\hline Unemployment & 567 & 9.55 & 6.88 & 29.80 \\
\hline Education & & 6.63 & 9.56 & 12.66 \\
\hline Political In. & 567 & -0.53 & 0.89 & 85.00 \\
\hline Buss.F & 567 & 53.17 & 20.07 & 89.00 \\
\hline Trad.F & 567 & 51.31 & 25.37 & 70.00 \\
\hline Finan.F & 567 & 39.26 & 18.53 & 2488.86 \\
\hline High.TE & 567 & 108.82 & 336.95 & 1486.10 \\
\hline Cost.SAB & 567 & 65.22 & 151.16 & 225.02 \\
\hline Trad.OEI & 567 & 61.30 & 37.32 & 1.08 \\
\hline Rule of law & 567 & -0.49 & 0.61 & 70.00 \\
\hline Prop.R & 567 & 34.48 & 17.03 & \\
\hline
\end{tabular}

Source: Own elaboration.

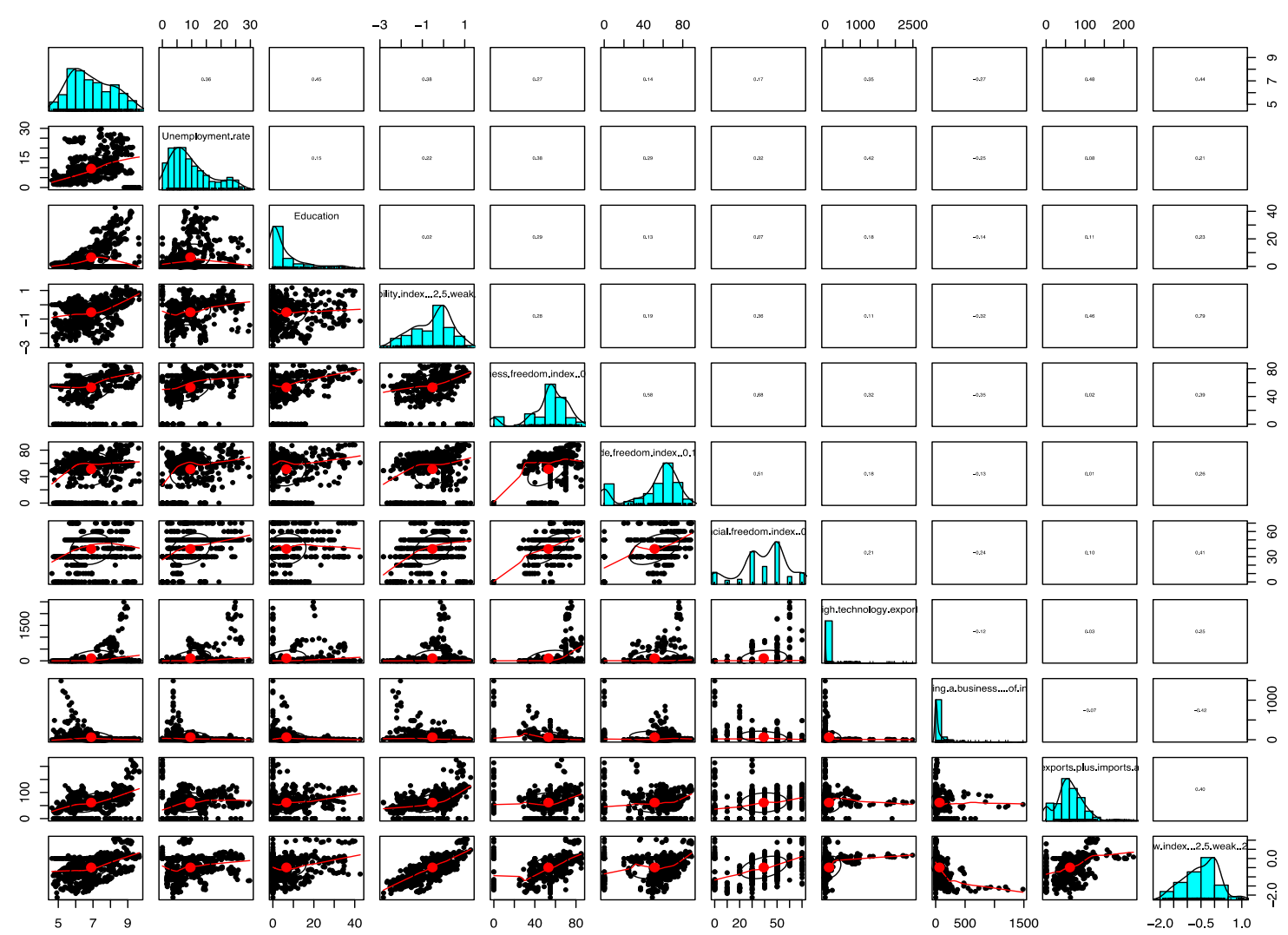

Figure 3. Correlation Matrix

Source: Own elaboration 


\section{ANALYSIS/STUDY DISCUSSION}

Table 3

Analysis Results

\begin{tabular}{|c|c|c|c|}
\hline & MODEL 1 & MODEL 2 & MODEL 3 \\
\hline GDP.PC & $\begin{array}{l}1.034^{* * * *} \\
(0.101)\end{array}$ & $\begin{array}{l}0.815^{* * *} \\
(0.116)\end{array}$ & $\begin{array}{l}0.867^{* * *} \\
(0.108)\end{array}$ \\
\hline Unemployment & $\begin{array}{l}0.112^{* * *} \\
(0.015)\end{array}$ & $\begin{array}{l}0.099 * * * \\
(0.011)\end{array}$ & $\begin{array}{l}0.107 * * * \\
(0.011)\end{array}$ \\
\hline Education & $\begin{array}{l}0.044^{* * *} \\
(0.011)\end{array}$ & $\begin{array}{l}0.058^{* * *} \\
(0.016)\end{array}$ & $\begin{array}{l}0.036^{*} \\
(0.013)\end{array}$ \\
\hline Political.in & & $\begin{array}{l}-0.973^{* * *} \\
(0.1756)\end{array}$ & $\begin{array}{l}-0.813^{* * *} \\
(0.169)\end{array}$ \\
\hline Buss.F & & $\begin{array}{l}-0.005 \\
(0.0064)\end{array}$ & $\begin{array}{c}-0.013^{*} \\
(0.006)\end{array}$ \\
\hline Trad.F & & $\begin{array}{l}0.002 \\
(0.004)\end{array}$ & $\begin{array}{l}0.007 \\
(0.004)\end{array}$ \\
\hline Finan.F & & $\begin{array}{l}0.026^{* *} \\
(0.0096)\end{array}$ & $\begin{array}{l}0.029 * * * \\
(0.006)\end{array}$ \\
\hline High.TE & & $\begin{array}{l}0.001^{* * *} \\
(0.000)\end{array}$ & $\begin{array}{l}0.001^{* * *} \\
(0.000)\end{array}$ \\
\hline Cost.SAB & & $\begin{array}{l}0.0004 \\
(0.000)\end{array}$ & $\begin{array}{l}0.0005 \\
(0.000)\end{array}$ \\
\hline Trad.OEI & & $\begin{array}{l}-0.032^{* * *} \\
(0.0037)\end{array}$ & $\begin{array}{l}-0.029 \text { *** } \\
(0.003)\end{array}$ \\
\hline Rule.of.law & & $\begin{array}{l}1.233^{* * *} \\
(0.349)\end{array}$ & $\begin{array}{l}0.525 \\
(0.288)\end{array}$ \\
\hline Christians & & & $\begin{array}{l}-0.003 \\
(0.003)\end{array}$ \\
\hline Muslims & & & $\begin{array}{l}0.014^{* * *} \\
(0.003)\end{array}$ \\
\hline Intercept & $\begin{array}{l}-5.533^{* * *} \\
(0.644)\end{array}$ & $\begin{array}{l}-3.447^{* * *} \\
(0.516)\end{array}$ & $\begin{array}{c}-4.635^{* * *} \\
(0.636)\end{array}$ \\
\hline $2 \times$ log-likelihood & -3605.0860 & -3494.9400 & -3465.2350 \\
\hline Theta & 0.1731 & 0.2247 & 0.2415 \\
\hline AIC & 3615.1 & 3520.9 & -3465.2350 \\
\hline Wald test & & $2.2 \mathrm{e}-16 * * *$ & $2.2 \mathrm{e}-16 * * *$ \\
\hline
\end{tabular}

Source: Own elaboration. 
Note: Summary of fitted count regression models (negative binomial estimate): coefficient estimates (with Wald standard errors in parantheses), number of estimated parameters, maximized log-likelihood, AIC, and theta

Table 3 above shows the results of the negative binomial model, which was identified as a fitting estimate because of the over-dispersed nature of the dependent variable. Model one tests the control variables on the dependent variable. All the factors indicate a strong positive relationship with the dependent variable. The only factor which had a different outcome to that which was expected was unemployment, which shows a positive effect on the number of patents. This can be explained by number of factors, but the most significant one is freedom of entrepreneurship because it tends to make people work more creatively to ensure the means of their subsistence in an uncertain economy.

Model 2 includes the control variables and the research variables. We realize that political instability is negatively significant, and that the rule of law is positively significant. Other factors, such as business freedom and openness to trade, are negatively significant while high technology export and financial freedom are positively significant.

In model 3 we added the two religious groups in Africa which are dominant, to determine how they influence political instability. The third model shows a reduction in the coefficient of political instability, from -0.973 to -0.813 and Islam plays a significant role here. However, the rule of law in the third model is not significant.

The role of institutions in determining the functionality of companies is something that cannot be neglected. Political uncertainty and changes in government are the main factors influencing the sustainability and development of the continent. Alesina et al. (1996) state that political instability has an effect on the economic performance of a country. This supports our first hypothesis: political instability negatively affects patenting activity. The data show that countries with poorly developed institutions have less patent applications per resident; this instability discourages investment and promotes emigration. Citizens have confidence in their country when there is stability, and this promotes growth and increases investors' appetite to invest in the economy. A lot of Africans prefer investing abroad because of the uncertainty. Instability increases the risk of any investment twice as much than in a stable country.

Rule of law positively influences a building of trust which therefore increases the willingness of people to innovate. When people have trust in their country, they feel safe. Rigobon et al. (2005) identified the rule of law as a positive factor for economic performance. Patenting is a way that innovators protect their intellectual property, so when a country has rules that are effective, it increases the trust of the citizens to produce more. The data makes it clear that when a country has efficient institutions the number of patents is also high.

Openness to trade has a negative effect on patenting activity, which is confirmed by the findings of Rigobon. This factor discourages the developed countries from any involvement in the developing countries as they face the problems related to weak institutions, political uncertainty and regulatory inconsistency. The above-mentioned factors must rather give way to transparency and accountability in governance, backed by a political will to ensure and promote regional integration and backward integration.

\section{CONCLUSION}

Our research was aimed at finding the effects of political instability on patent activity (Innovation). We also discovered that the confidence of people in their political system encourages innovation, investment and promotion of patent activities in businesses. When the political climate is favourable, it 
encourages entrepreneurs to explore opportunities in their own countries. Countries need to restructure their innovation approach by creating a good institutional environment.

\section{ACKNOWLEDGEMENT}

The authors are thankful to the Russian Ministry of Education and Science, DAAD, The Ministry of Science and Higher Education in Poland for financial support to carry out this research. Thanks (IOS, Regensburg) for hosting James Okrah for the period of his research internship with them, with special thanks to Dr Alexander Nepp (Supervisor), Dr. Olga Popova (IOS, Regensburg), Prof. Richard Frensch (IOS, Regensburg) and Dr Stefan Huber for their support.

\section{REFERENCES}

Acemoglu, D., Johnson S., \& Robinson J. A. (2001). The colonial origins of comparative development: An empirical investigation. American Economic Review 91(5), 1369-1401.

Akan, T. (2016). Institutional System Analysis in Political Economy: Neoliberalism, Social Democracy and Islam. Routledge, London and New York.

Alesina, A., Özler, S., Roubini, N., \& Swagel, P. (1996). Political instability and economic growth. Journal of Economic growth, 1(2), 189-211.

Barley, S. R., \& Tolbert, P. S. (1997). Institutionalization and structuration: Studying the links between action and institution. Organization Studies, 18(1), 93-117.

Boxenbaum, E., \& Jonsson, S. (2008). Isomorphism, diffusion and decoupling. In R. Greenwood, C. Oliver, K. Sahlin \& R. Suddaby (Eds.), Handbook of organizational institutionalism. Thousand Oaks, CA: SAGE, 78.

Carlsson, B., Jacobsson, S., Holmén, M., \& Rickne, A. (2002). Innovation systems: analytical and methodological issues. Research policy, 31(2), 233-245.

Chudy-Laskowska K., Jankowska-Mihułowicz M., Piecuch T. (2017).Analiza poziomu innowacyjności polskich przedsiębiorstw. Ekonomika i organizacja przedsiebiorstwa, 11, 91-107.

Danaj, A., Lazányi, K., \& Bilan, Y. (2018). Perceptions and Implications of Immigration in France - Economic, Social, Political and Cultural Perspectives. Economics and Sociology, 11(3), 226-247.

Denison, M., \& Vidra, R. K. (2013). Analytical Frameworks for Assessing ICT and Agribusiness Ecosystems For Application in Ghana and Kenya, LSE Enterprise, from: https://assets.publishing.service.gov.uk/media/57a08a05ed915d3cfd00054c/Analytical_Frameworks_for_As sessing_ICT_and_Agribusiness_Ecosystems.pdf.

DiMaggio,. P. J., \& Powell, W. W. (1983). The iron cage revisited: Institutional isomorphism and collective rationality in organizational fields, American Sociological Review 48, 147-160.

Draskovic, V., Draskovic, M., \& Bilan, S. (2019). Motivation, methodology, and phenomenology of institutional nihilism in the SEE countries. Montenegrin Journal of Economics, 15(2), 7-14.

Freeman, C. (1995). The 'National System of Innovation' in historical perspective. Cambridge Journal of Economics, 19(1), 5-24.

Grossman, G. M., \& Helpman, E. Innovation and growth in the global economy. The MIT Press, 1993.

Guiso, L., Sapienza, P., \& Zingales, L. (2003). People's opium? Religion and economic attitudes. Journal of Monetary Economics, 50(1), 225-282.

Hajduk-Stelmachowicz M. (2018), Audyt energetyczny przedsiębiorstw jako wyzwanie w kontekście poprawy efektywności energetycznej, [w: ] Zeszyty Naukowe Instytutu Gospodarki Surowcami Mineralnymi i Energia Polskiej Akademii Nauk, Zeszyt nr 104, s. 43-54.

Harold B. J Jr, Furnham A., \& Deile A. J. (2010), Religious orientation and the Protestant Work Ethic. Mental Health, Religion \& Culture, 13(7-8), 697-706.

Harper, C., Jones, N., \& Watson, C. (2012). Gender justice for adolescent girls: tackling social institutions. Towards a conceptual framework. Report. London: Overseas Development Institute from: https://www.odi.org/sites/odi.org.uk/files/odi-assets/publications-opinion-files/8746.pdf 
Heller, M. A., \& Eisenberg, R. S. (1998). Can patents deter innovation? The anticommons in biomedical research. Science, 280(5364), 698-701.

Hentz, J. J., \& Solomon, H. (Eds.). (2017). Understanding Boko Haram: terrorism and insurgency in Africa. Routledge Taylor $\&$ Francis. Abingdon, Oxon; New York, NY.

Hoti, S., \& McAleer, M. (2006). How does country risk affect innovation? An application to foreign patents registered in the USA. Journal of Economic Surveys, 20(4), 691-714.

Huang, Peng, Tafti A., R., \& Mithas S. (2018). Platform Sponsor's Investments and User Contributions in Knowledge Communities: The Role of Knowledge Seeding, MitSloan Management Review, 59(3), 10-13.

Ivanov, D., Dolgui, A., Sokolov, B., \& Ivanova, M. (2017). Literature review on disruption recovery in the supply chain. International Journal of Production Research, 55(20), 6158-6174.

Jaffe, A. B., \& Palmer, K. (1997). Environmental regulation and innovation: a panel data study. Review of Economics and Statistics, 79(4), 610-619.

Jovovic, R., Draskovic, M., Delibasic, M., \& Jovovic, M. (2017). The concept of sustainable regional development institutional aspects, policies and prospects. Journal of International Studies, 10(1), 255-266. doi:10.14254/2071$8330.2017 / 10-1 / 18$

Jütting, J., Drechsler D., Bartsch, S. \& de Soysa, I. (eds.) (2007). Informal institutions: How social norms help or hinder development. Development Centre Studies, OECD, Paris.

Kahane, B. (2012). "Tikkun Olam": how a Jewish ethos drives innovation. Journal of Management Development, 31(9), 938-947.

Leftwich, A. \& Sen, K. (2010). Beyond institutions: Institutions and organizations in the politics and economics of poverty reduction - Thematic synthesis of research evidence. DFID-funded Research Programme Consortium on Improving Institutions for Pro-Poor Growth (IPPG). Manchester. University of Manchester.

Lehrer, E. L. (1995). The effects of religion on the labor supply of married women. Social Science Research, 24(3), 281301.

Lehrer, E. L. (1996). Religion as a determinant of marital fertility. Journal of Population Economics, 9(2), 173-196.

Lehrer, E. L. (1999). Religion as a determinant of educational attainment: An economic perspective. Social Science Research, 28(4), 358-379.

Levchenko, Andrei A. (2007). Institutional quality and international trade. The Review of Economic Studies 74(3), 791819.

Lundvall, B- A., Dosi, G., \& Freeman, C. (1988). Innovation as an interactive process: from user-producer interaction to the national system of innovation., In: Dosi, G. et. al. (eds.) (Ed.), Technical Change and Economic Theory, 349-369.

Lundvall, B-Å. (1992). User - Producer Relationships, National Systems of Innovation and Internationalisation. In: National Systems of Innovation: Towards a Theory of Innovation and interactive learning. Lundvall, B-A. (ed.) Frances Pinter Publishers Ltd., London, 45-67.

Lundvall, B-A. (2002). Innovation, growth, and social cohesion: the Danish model. New Horizons in the economics of innovation. Edward Elgar Publishing. Cheltenham, UK, Northampton, MA, USA.

McCleary, R. M., \& Barro, R. J. (2006). Religion and economy. Journal of Economic Perspectives, 20(2), 49-72.

Navickas, V., Navickas, M., \& Kordoš, M. (2016). Corruption effect on foreign direct investments in European Union countries. Business: Theory and Practice, 17(4), 299-306.

North, D. C. (1990). Institutions, institutional change, and economic performance. Cambridge University Press, Cambridge, New York.

Ortiz-Villajos, J. M., \& Sotoca, S. (2018). Innovation and business survival: A long-term approach. Research Policy 47(8), 1418-1436.

Pittaway, L., Robertson, M., Munir, K., Denyer, D., \& Neely, A. (2004). Networking and innovation: a systematic review of the evidence. International Journal of Management Reviews, 5-6 (3-4), 137-168.

Polterovich, V. (2017). Positive collaboration: Factors and mechanisms of evolution. Russian Journal of Economics, 3(1), 24-41.

Rigobon, R.,\& Rodrik D. (2005). Rule of law, democracy, openness, and income: Estimating the interrelationships. The Economics of Transition and Institutional Change, 13(3), 533-564. 
Schwab, K. (2018). World Economic Forum. The Global Competitive Report 2018, World Economic Forum. Cologny/Geneva, Switzerland from: http://www3.weforum.org/docs/GCR2018/05FullReport/TheGlobalCompetitivenessReport2018.pdf

Tang, T. L.-P. (1995). The development of a short money ethic scale: Attitudes toward money and pay satisfaction revisited. Personality and individual differences, 19(6), 809-816.

Unsworth, S.(2010). An upside down view of governance. Institute of Development Studies, Brighton. From: http://www2.ids.ac.uk/gdr/cfs/pdfs/AnUpside-downViewofGovernance.pdf

Waguespack, D. M., Birnir, J. K., \& Schroeder, J. (2005). Technological development and political stability: Patenting in Latin America and the Caribbean. Research policy, 34(10), 1570-1590.

Ward, C (2017). Anarchy in Action. PM Press.

Weber, M. (1905). 1992: Die protestantische Ethik und der Geist des Kapitalismus. Gesammelte Aufsätze zur Religionssoziologie.

Witkowska D., Kompa K., \& Mentel G. (2019). The effect of government decisions on the efficiency of the investment funds market in Poland. Journal of Business Economics and Management, 20(3).

Zeileis, A., Kleiber, C., \& Jackman, S. (2008). Regression models for count data in R. Journal of Statistical Software, $27(8), 1-25$. 